\title{
Proceeding
}

Supplementary Issue: Winter Conferences of Sports Science. International Conference of Engineering, Innovation Technology and Applied Science.

\section{Kicking ability in pencak silat, reviewed from eye-foot coordination, speed, and ratio of limb length-body height}

\author{
NUR SUBEKTI , VERA SEPTI SISTIASIH, AGAM AKHMAD SYAUKANI, MUHAD FATONI \\ Faculty of Teacher Training and Education, University Muhammadiyah Surakarta, Indonesia
}

\begin{abstract}
The purpose of this study is to determine the correlation between eye-foot coordination (both single and double), speed, and limb length-body height ratio with the ability to perform (sickle) kicks in pencak silat and how much the contribution of each of these attributes. Correlation study was performed with data collection techniques through performance evaluation tests on each variable. 30 male athletes of Pencak Silat Club of Universitas Muhammadiyah Surakarta (UMS) with height criteria $(163-165 \mathrm{~cm})$ were willing to participate in this study. The results showed that each variable had a significant correlation, both single and double. Eyefoot coordination and speed have a significant correlation with kicking ability in pencak silat, both with or without controlling other supporting variables. While the ratio of limb length to body height has a correlation with kicking ability if influenced by eye-foot coordination and speed. Eye-foot coordination makes a relative contribution (52.17\%), effective (35.11\%), speed makes a relative contribution (35.75\%), effective (24.06\%), and the ratio of limb length to body height makes a relative contribution $(12.02 \%)$, effective $(8.09 \%)$. The total effective contribution of the independent variables to the dependent variables is $67.26 \%$. Thus, to improve the ability to perform kicks in pencak silat, an athlete should be able to take advantage of eye-foot coordination and to exert speed by contributing a good ratio of limb length-body height according to the demands of pencak silat.
\end{abstract}

Keywords: Pencak silat kicks; Eye-foot coordination; Speed; Ratio of limb length-body height.

\section{Cite this article as:}

Subekti, N., Sistiasih, V.S., Syaukani, A.A., \& Fatoni, M. (2020). Kicking ability in pencak silat, reviewed from eye-foot coordination, speed, and ratio of limb length-body height. Journal of Human Sport and Exercise, 15(2proc), S453-S461. doi:https://doi.org/10.14198/ihse.2020.15.Proc2.36

Corresponding author. Faculty of Teacher Training and Education, Universitas Muhammadiyah Surakarta, Jawa Tengah 57102, Indonesia.

E-mail: ns584@ums.ac.id

Supplementary Issue: Winter Conferences of Sports Science. International Conference of Engineering, Innovation Technology and Applied Science.

JOURNAL OF HUMAN SPORT \& EXERCISE ISSN 1988-5202

(c) Faculty of Education. University of Alicante

doi:10.14198/jhse.2020.15.Proc2.36 


\section{INTRODUCTION}

Pencak silat is a martial art known as one of the cultural heritage of the Malay Archipelago which has gained international recognition (Aziz, Benedict and Teh, 2002). The sport of pencak silat is now increasingly showing positive developments, as evidenced by the increasing number of pencak silat competitions. The development of pencak silat at this time can be proven by the increasing density of events, ranging from elementary schools, adolescents, adults, and even to multi-sport events at the Asian level and the invitation of world championships (Siswantoyo and Graha, 2016). Pencak silat gained popularity since becoming one of the sports that was competed in the Asian Games in 2018, where the Indonesian team managed to become the General Champion by winning 14 gold medals. The aspects of thinking and creativity might improve the winning motivation (Puspitasari et al., 2019).

The basic principle of a pencak silat match is full body contact fighting in which there is an element of attack and defence. Attacks or defences can be performed using kicking techniques, punches, and takedowns. In the competition category, kicking technique is the dominant one, so it receives a special focus in training process (Nugroho, 2004; Iswana and Siswantoyo, 2013; Hariono, Rahayu and Sugiharto, 2017). Agung Nugroho (2004) has found that the percentage of dominant kick techniques performed in matches reaches $47 \%$.

Pencak silat is categorized as a sport with complex movements performed at high speed with good stamina. Such intense martial art requires the support of physical abilities, namely: (strength, power, speed, and muscular endurance) that must be involved during the process of training and competition (Lenetsky and Harris, 2012; James et al., 2016). The results of a study conducted by loannis N. Kostikiadis et al (2018) showed that physical condition training designed according to the demands of sports competition has a significant impact on improving athlete performance (Kostikiadis et al., 2018). Likewise, Agung Nugroho (2012) shows that athletes in the martial arts category (pencak silat, taekwondo, karate, kempo, judo, tarung derajat and wushu) require good physical condition, such as: strength, power, speed, endurance, coordination, flexibility, balance, and agility.

Physical aspect is a very basic component to determine the ability of an athlete to complete an exercise program (Murzinova et al, 2018), as well as maintaining excellent conditions in a match. However, physical factors that are anatomical must not be ignored. The anatomical factors or commonly said as body posture also provide its own advantages in sports. Ideal body shape in accordance with the sport is one of the requirements that can affect the achievements in it. Sajoto (1988: 11) states "One aspect of achieving achievement in sports is the biological aspect which includes the structure and posture of body, such as body height, limb length, size, width, weight, and somatotype (body shape)" (Sajoto, 1988).

Improvement of pencak silat skills is significantly influenced by physical abilities and technical skills which is a necessity that must be possessed by every pencak silat athlete. The training program is arranged in accordance with the variables that affect the ability of pencak silat kicks and is given appropriately and in accordance with the growth and development of the physical condition of the athlete. The role of eye-foot coordination, speed, ratio of limb length-body height can be seen through the contribution of each variable to the ability of performing pencak silat sickle kick. Because the contribution of each variable is not yet known, the research is conducted first.

The shortcomings that can be seen so far is the lack of information and research on the relationship between the physical and anthropometric components to kicking ability in pencak silat. Therefore, the aim of the study 
is to investigate the relationship (both single and double) between the variables of eye-foot coordination, speed, and the ratio of limb length-body height with the ability to perform special kicks in pencak silat and how much the contribution of each of these variables.

\section{METHODS}

\section{Participants}

Thirty (30) athletes participated in this study, determined by the criteria of male sex and having a height between 163 to $165 \mathrm{~cm}$ from the Pencak Silat Club of Universitas Muhammadiyah Surakarta (UMS), Central Java, Indonesia. Sampling is carried out based on individual and researchers considerations and advice from a team of experts. Based on the sampling technique, 30 male athletes were chosen.

\section{Procedure}

Data collection techniques used in this study were tests and measurements. The types of tests used in this study are as follows: 1) Eye-foot Coordination Test: Coordination is defined as a harmonious relationship and mutually influential relationships between muscle groups during work, aimed at various skill levels. Coordination in this study is referred to as eye-foot coordination. Measurement of eye-foot coordination was performed using soccer wall volley. 2) Speed Test: The speed here refers to running speed of the pencak silat athletes. The test is to investigate whether running speed has an effect on the ability of performing pencak silat sickle kicks. In this speed test the fighter ran as fast as possible on a running track of 20 meters. 3) Limb Length-Body Height Ratio: Legs are lower limbs consisting of the entire leg, from the groin to the feet. What is meant by limb in this research are lower limbs (legs) consisting of free lower limb bones (skeleton extremitas inferior liberae). Height here is calculated as the length of the body when sitting, from the floor to the top of the head (vertex) in centimetres. Essentially, the ratio of limb length to body height here is referred as the ratio between leg length and body height minus leg length. Comparison or ratio is obtained by dividing leg length by height times 100\%. Leg length and body height are measured in cm. 4) Kicking Ability: kicking ability of pencak silat, measured by performing sickle kicks, right and left sickle kicks as much as possible on the target for 15 seconds. The results recorded are the number of kicks that can be taken and are valid regarding the specified target during the 15 seconds.

\section{Statistical analysis}

Statistical data descriptions (mean \pm standard deviation) and (highest score, lowest score) are determined to measure derived variables. Data analysis in this study uses techniques of regression analysis and partial correlation. Multiple regression analysis is the development of simple analysis, utilized to predict the value of the dependent variable $(Y)$ if the independent variable is at least two or more. According to Somantri and Muhidin (2006: 243) multiple regression analysis is used to examine the relationship between two or more variables, especially to explore the pattern of relationships whose models are not yet fully known, or to find out how variations of several independent variables $(X 1),(X 2),(X 3) \ldots(X n)$ influences the dependent variable in a complex phenomenon (Somantri and Muhidin, 2006). Partial correlation analysis is utilized to find out how strong the relationship of one independent variable to the partially dependent variable and the other independent variable is considered constant. Data were analysed using SPSS version 17.0, a probability level of $5 \%$ was utilized to indicate the level of statistical significance.

\section{RESULTS}

Statistical description of the variables eye-foot coordination (X1), speed (X2), ratio of limb length to body height (X3) and kicking ability of pencak silat (Y) of 30 male athletes in Pencak Silat Club of Universitas Muhammadiyah Surakarta (UMS), Central Java, Indonesia is shown in Table 1. Data description of each 
variable obtained (average \pm standard deviation) and (highest score, lowest score): eye-foot coordination (X1) of $(18.00 \pm 4.613)$ and $(+26 ;-11)$, speed $(X 2)$ of $(3.24 \pm 0.215)$ and $(+3.64 ;-2.90)$, the ratio of limb length to body height $(X 3)$ of $(51.08 \pm 1.099)$ and $(+52.88 ;-48.79)$, and the kicking ability of pencak silat $(Y)$ is $(35.13 \pm 5.178)$ and $(+45 ;-26)$.

Table 1. Statistical description.

\begin{tabular}{lcccc}
\hline \multirow{2}{*}{ Variable } & \multicolumn{4}{c}{$(\mathrm{n}=30)$} \\
\cline { 2 - 5 } & Mean & SD & $(+)$ & $(-)$ \\
\hline X1 & 18.00 & 4.613 & 26 repetition & 11 repetition \\
X2 & 3.24 & 0.215 & 3.64 seconds & 2.90 seconds \\
X3 & 51.08 & 1.099 & 52.88 & 48.79 \\
Y & 35.13 & 5.178 & 45 repetition & 26 repetition \\
\hline
\end{tabular}

Hypothesis testing is performed using SPSS version 17.0, with results of correlation analysis, and double regression with ( $N=30$ dan $r_{\text {tabel }} 5 \%=0.361$ ) between the eye-foot coordination test data $(X 1)$, speed $(X 2)$, the ratio of limb length to body height $(X 3)$, and the special kicking ability of pencak silat $(Y)$ are presented in Table 2. Eye-foot coordination (X1) has a significant positive correlation with kicking ability in pencak silat (Y) with the correlation coefficient $r_{\text {count }}=0.734>r_{\text {table }} 5 \%=0.361$. Speed $(X 2)$ has a significant inverse correlation with the ability of special pencak silat kick $(Y)$ with the correlation coefficient $r_{\text {count }}=-0.687>r_{\text {table }} 5 \%=0.361$. Limb length-body height ratio $(\mathrm{X} 3)$ has a significant positive correlation with kicking ability in pencak silat (Y) with the correlation coefficient $r_{\text {count }}=0.529>r_{\text {table }} 5 \%=0.361$.

Eye-foot coordination $(X 1)$ and speed $(X 2)$ have a significant positive correlation with the special kicking ability of pencak silat $(Y)$ with the correlation coefficient $r_{\text {count }}=0.810>r_{\text {table }} 5 \%=0.361$. Eye-foot coordination (X1) and limb length-body height ratio (X3) have a significant positive correlation with ability of special pencak silat kicks $(Y)$ with the correlation coefficient $r_{\text {count }}=0.773>r_{\text {table }} 5 \%=0.361$. Speed $(X 2)$ and limb lengthbody height ratio $(\mathrm{X} 3)$ have a significant positive correlation with the ability of special pencak silat kicks $(\mathrm{Y})$ with a correlation coefficient $r_{\text {count }}=0.721>r_{\text {table }} 5 \%=0.361$. Eye-foot coordination $(X 1)$, speed $(X 2)$, and limb length-body height ratio $(\mathrm{X} 3)$ have a significant positive correlation with kicking ability of pencak silat $(\mathrm{Y})$ with the correlation coefficient $r_{\text {count }}=0.821>r_{\text {table }} 5 \%=0.361$.

Table 2. Summary of correlation and multiple regression analysis results.

\begin{tabular}{llll}
\hline Correlation & $\mathbf{N}$ & $\mathbf{r}_{\text {count }}$ & $\mathbf{r}_{\text {table }}$ \\
\hline $\mathrm{X} 1-\mathrm{Y}$ & 30 & 0.734 & 0.361 \\
$\mathrm{X} 2-\mathrm{Y}$ & 30 & -0.687 & 0.361 \\
$\mathrm{X} 3-\mathrm{Y}$ & 30 & 0.529 & 0.361 \\
$\mathrm{X} 1, \mathrm{X} 2-\mathrm{Y}$ & 30 & 0.810 & 0.361 \\
$\mathrm{X} 1, \mathrm{X} 3-\mathrm{Y}$ & 30 & 0.773 & 0.361 \\
$\mathrm{X} 2, \mathrm{X} 3-\mathrm{Y}$ & 30 & 0.721 & 0.361 \\
$\mathrm{X} 1, \mathrm{X} 2, \mathrm{X} 3-\mathrm{Y}$ & 30 & 0.821 & 0.361 \\
\hline
\end{tabular}

Meanwhile, to investigate the value of contribution of each independent variable $(X)$ to the dependent variable (Y) by eliminating the influence of other independent variables (constant), partial correlation analysis is utilized. The results of the partial correlation analysis on each of the predictors of this study are presented in Table 3. 
From the results of the partial correlation analysis with ( $\mathrm{df}=26$ and $\mathrm{r}_{\text {table }} 5 \%=2.056$ ) the following information is obtained: Eye-foot coordination (X1) has a significant positive correlation with the ability of special pencak silat kicks $(Y)$ controlling speed $(X 2)$ with $\left(\rho=.590\right.$ and $\left.t_{\text {count }}=3.726>t_{\text {table }} 5 \%=2.056\right)$. Eye-foot coordination $(\mathrm{X} 1)$ has a significant positive correlation with the ability of special pencak silat kicks $(Y)$ to control the ratio of limb length-body height $(X 3)$ with $\left(\rho=.656\right.$ and $\left.t_{\text {count }}=4.432>t_{\text {table }} 5 \%=2.056\right)$.

Speed (X2) has a significant positive correlation with the ability of special pencak silat kicks $(\mathrm{Y})$ to control eye-foot coordination (X1) with $\left(\rho=.504\right.$ and $\left.t_{\text {count }}=2.975>t_{\text {table }} 5 \%=2.056\right)$. Speed $(X 2)$ has a significant positive correlation with the ability of special pencak silat kicks $(Y)$ to control the ratio of limb length-body height $(X 3)$ with $\left(\rho=.577\right.$ and $\left.t_{\text {count }}=3.602>t_{\text {table }} 5 \%=2.056\right)$.

Leg length-height ratio $(X 3)$ has a significant positive correlation with the ability of special pencak silat kick (Y) to control eye-foot coordination (X1) with $\left(\rho=.357\right.$ and tcount $\left.=1.949>t_{\text {table }} 5 \%=2.056\right)$. Limb lengthbody height ratio $(\mathrm{X} 3)$ has a significant positive correlation with the ability of pencak silat kicks $(\mathrm{Y})$ to control the speed $(X 2)$ with $\left(\rho=.298\right.$ and $\left.t_{\text {count }}=1.592>t_{\text {table }} 5 \%=2.056\right)$.

Eye-foot coordination (X1) has a significant negative correlation with the ratio of limb length-body height $(X 3)$ controlling speed $(X 2)$ with $\left(\rho=.207\right.$ and tcount $\left.=1.079<t_{\text {table }} 5 \%=2.056\right)$. Limb length-body height ratio $(X 3)$ has a significant negative correlation with speed $(X 2)$ controlling eye-foot coordination (X1) with $(\rho=.350$ and $\left.t_{\text {count }}=1.905<t_{\text {table }} 5 \%=2.056\right)$. Speed $(X 2)$ has a significant positive correlation with eye-foot coordination (X1) controlling the ratio of limb length-body height $(X 3)$ with $\left(\rho=.427\right.$ and $t_{\text {count }}=2.408>t_{\text {table }}$ $5 \%=2.056)$.

Eye-foot coordination $(\mathrm{X} 1)$ has a significant positive correlation with the ability of pencak silat kick $(\mathrm{Y})$ to control the speed (X2) and the ratio of limb length-body height (X3) with $\left(\rho=.566\right.$ and $t_{\text {count }}=3.501>$ table $5 \%=2.056)$. Speed $(X 2)$ has a significant positive correlation with the ability of pencak silat kicks $(Y)$ controlling eye-foot coordination (X1) and the ratio of limb length-body height $(X 3)$ with $(\rho=.434$ and tcount $=$ $\left.2.456>t_{\text {table }} 5 \%=2.056\right)$. Limb length-body height ratio $(X 3)$ has a significant negative correlation with kicking ability in pencak silat $(Y)$ controlling eye-foot coordination (X1) and speed $(X 2)$ with $\left(\rho=.222\right.$ and $t_{\text {count }}=$ $1.161<$ table $5 \%=2.056$ ).

Table 3. Summary of partial correlation analysis results.

\begin{tabular}{lcccccc}
\hline Variable control & & Correlation & Sign & Df & $\mathbf{t}_{\text {count }}$ & $\mathbf{t}_{\text {table }}$ \\
\hline X2 & X1Y & .590 & .001 & 26 & 3.726 & 2.056 \\
X3 & X1Y & .656 & .000 & 26 & 4.432 & 2.056 \\
X1 & X2Y & -.504 & .005 & 26 & -2.975 & 2.056 \\
X3 & X2Y & -.577 & .001 & 26 & -3.602 & 2.056 \\
X1 & X3Y & .357 & .058 & 26 & 1.949 & 2.056 \\
X2 & X3Y & .298 & .117 & 26 & 1.592 & 2.056 \\
X2 & X1X3 & .207 & .281 & 26 & 1.079 & 2.056 \\
X1 & X3X2 & -.35 & .062 & 26 & -1.905 & 2.056 \\
X3 & X2X1 & -.427 & .21 & 26 & -2.408 & 2.056 \\
X2andX3 & X1Y & .566 & .002 & 26 & 3.501 & 2.056 \\
X1andX3 & X2Y & -.434 & .021 & 26 & -2.456 & 2.056 \\
X1andX2 & X3Y & .222 & .255 & 26 & 1.161 & 2.056 \\
\hline
\end{tabular}


Further analysis using multiple regression analysis of three predictors revealed the relationship between all independent variables: eye-foot coordination (X1), speed (X2), leg length to body height ratio (X3), with the dependent variable the ability of pencak silat sickle kick $(Y)$ presented in Table 4. From the analysis obtained information that there is a strong and significant relationship between the independent variables $(X 1, X 2, X 3)$ with the dependent variable $(Y)$, namely the simultaneous correlation coefficient $\left(R_{1,2,3}=0.821\right)$ and has a determination coefficient of $67 \%$. Significance test with regression $\mathrm{db}=\mathrm{m}$ versus $\mathrm{N}-\mathrm{m} 1=227 \mathrm{~F}_{\text {table }} 5 \%=$ 3.35; $F=17.866>$ null hypothesis (0). Thus, the null hypothesis $(0)$ is rejected, this shows that there is a significant relationship between eye-foot coordination $(X 1)$, speed $(X 2)$, ratio of limb length to body height (X3), with the special kicking ability of pencak silat $(Y)$.

Table 4. Summary of multiple predictions regression analysis

\begin{tabular}{|c|c|c|c|c|c|c|}
\hline \multirow{2}{*}{ Variable } & \multirow{2}{*}{$\frac{\text { Regression line }}{Y^{\wedge}}$} & \multirow{2}{*}{$\mathbf{R}_{(1,2,3)}$} & \multirow{2}{*}{$\mathbf{R}^{2}$} & \multicolumn{3}{|c|}{ Significance test } \\
\hline & & & & $\mathrm{Db}$ & $\mathrm{F}$ & Ftable \\
\hline Eye-Foot Coordination & $\begin{array}{c}15.512 \\
537\end{array}$ & & & & & \\
\hline Speed & $\begin{array}{c}.531 \\
-8.443\end{array}$ & 0.821 & 0.673 & 227 & 17.866 & 3.35 \\
\hline Ratio of Limb Length-Body Height & .723 & & & & & \\
\hline
\end{tabular}

The relative contribution and effective contribution of each independent variable: eye-foot coordination (X1), speed (X2), limb length to body height ratio (X3), with dependent variable the ability of pencak silat sickle kicks $(Y)$ can be seen in Figure 1. It shows that eye-foot coordination provides (relative contribution of $52.17 \%$ ) and (effective contribution of $35.11 \%$ ), speed (relative contribution of $35.75 \%$ ), and (effective contribution of $24.06 \%$ ), ratio of limb length to body height (relative contribution $12.02 \%$ ), and (effective contribution $8.09 \%$ ). Thus, the total effective development of the three variables on the ability of the sickle kick was $67.26 \%$. This shows the total contribution of all variables.

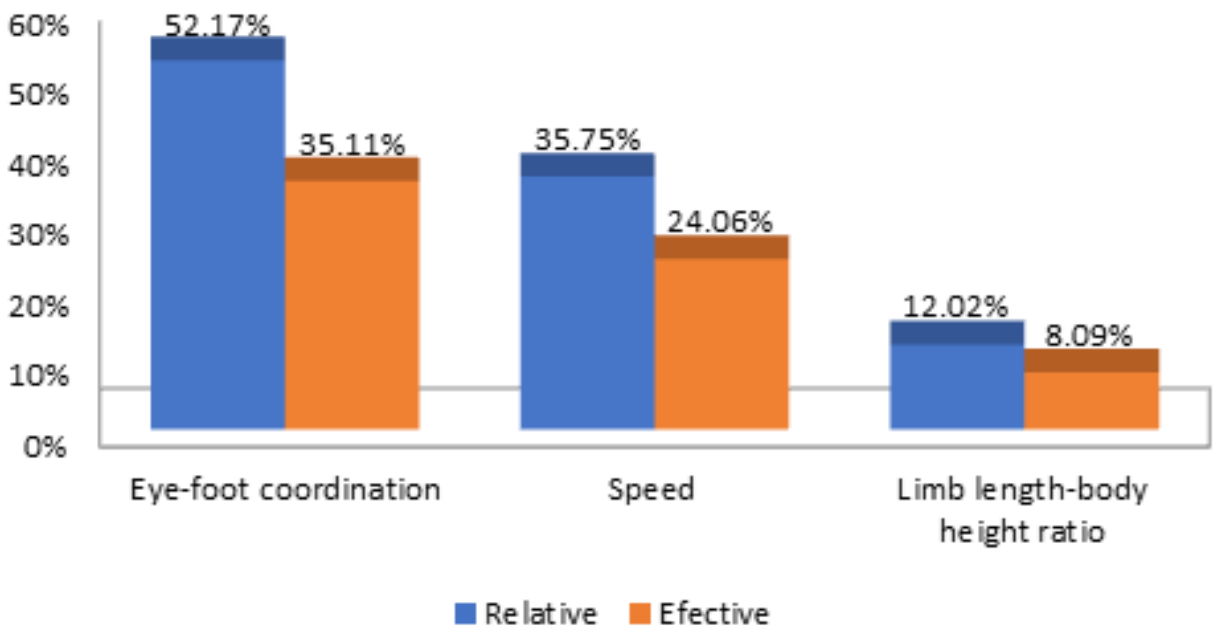

Figure 1. Relative and effective contributions of X1 (Eye-foot coordination), X2 (Speed), X3 (Limb lengthbody height ratio) to $Y$ (Kicking ability). 


\section{DISCUSSION}

In the first hypothesis testing, correlation analysis showed that eye-foot coordination (X1), speed (X2), and limb length to body height ratio (X3) have a significant positive correlation both single and double with pencak silat kick capabilities $(\mathrm{Y})$.

After further analysis using partial analysis to determine the contribution of each independent variable $(X)$ to the dependent variable $(Y)$ by eliminating the influence of other independent variables (constant), the results of the analysis show the difference in the ratio of limb length to body height $(X 3)$ does not have a positive correlation if it is not influenced by the other three variables, both single and double. While other variables: eye-foot coordination (X1), speed (X2), special kicking ability of pencak silat $(\mathrm{Y})$ have a positive correlation with each other without being influenced or influenced by other variables. The ratio of limb length to body height (X3) can affect kicking ability of pencak silat if it gets a contribution from eye-foot coordination (X1) and speed $(\mathrm{X} 2)$.

The results of this study indicate that physical condition factors; eye-foot coordination and speed have a significant positive correlation with the ability to perform special pencak silat kicks either single, double, and without the influence of other variables. While anthropometric factors, the ratio of limb length to body height affects the ability of the special pencak silat kicks if it gets a contribution from the physical condition variable.

Judging from the amount of relative and effective contribution, the variable of eye-foot coordination has the greatest contribution to the ability of pencak silat kicks namely $52.17 \%$ and $35.11 \%$. The same opinion is also found in studies of martial arts, mastering good techniques requires a high level of development of coordination from athlete (Myers, Nevill and Al Nakeeb, 2013; Santos et al., 2013; Alexander and Vladislav, 2016; Lariosa et al., 2017). In the process of training in martial arts techniques, developing coordination potential must be a priority (Alexander and Vladislav, 2018).

Variable speed has a medium category contribution to the ability of special pencak silat kicks that are $35.75 \%$ and $24.06 \%$. While the ratio of limb length to body height has a relatively small contribution to the ability of the special kick pencak silat, only $12.02 \%$ and $8.09 \%$.

\section{CONCLUSION}

From the results of this study, it can be concluded that physical and anthropometric factors have a significant correlation to the ability in sports, especially in the martial arts such as pencak silat. Eye-foot coordination and speed have a relationship with the ability of pencak silat sickle kicks. While the ratio of limb length to body height affects the ability of performing pencak silat kicks if it is influenced by physical condition variables.

To have a good kicking ability in pencak silat, an athlete should be able to take advantage of eye-foot coordination and to exert speed with the contribution of the good ratio of limb length - body height according to the demands of the martial art.

Furthermore, it is recommended that coaches pay serious attention and consider the variables that have a relationship and influence on the ability to perform kicks in pencak silat. The author also suggests conducting further research with a broad scope and observe the possibility of other variables that may also have a positive relationship with the ability to perform kicks in pencak silat. 


\section{CONFLICT OF INTERESTS}

The author declares that there is no conflict of interests regarding the text of this article.

\section{REFERENCES}

Alexander, B. and Vladislav, B. (2016) 'Factors that determine high efficiency in developing speed and strength abilities of female hurdlers', Journal of Physical Education \& Sport, 16(3), pp. 910-913.

Alexander, B. and Vladislav, B. (2018) 'Pedagogical practice for development of coordination potential of MMA fighters and estimation of its efficiency', Journal of Human Sport and Exercise, 13(1), pp. 72-88. https://doi.org/10.14198/jhse.2018.131.08

Aziz, A. R., Benedict, T. and Teh, K. C. (2002) 'Physiological responses during matches and profile of elite pencak silat exponents', Journal of Sports Science \& Medicine, 1(4), pp. 147-155.

Hariono, A., Rahayu, T. and Sugiharto (2017) 'Developing a performance assessment of kicks in the competition category of pencak silat martial arts', The Journal of Educational Development, 5(2), pp. 224-237.

Iswana, B. and Siswantoyo, S. (2013) 'Model latihan keterampilan gerak pencak silat anak usia 9-12 tahun', Jurnal Keolahragaan, 1(1), pp. 26-26. https://doi.org/10.21831/jk.v1i1.2343

James, L. P., Haff, G.G., Kelly, V.G., and Beckman, E.M.. (2016) 'Towards a determination of the physiological characteristics distinguishing successful mixed martial arts athletes: a systematic review of combat sport literature', Sports Medicine, 46(10), pp. 1525-1551. https://doi.org/10.1007/s40279-016-0493-1

Kostikiadis, I. N., Methenitis, S., Tsoukos, A., Veligekas, P., Terzis, G., and Bogdanis, G.C. (2018) 'The effect of short-term sport-specific strength and conditioning training on physical fitness of well-trained mixed martial arts athletes', Journal of Sports Science \& Medicine, 17(3), pp. 348-358.

Lariosa, C. J. D., Gozdowski, D., Pietkiewicz, S., and Maciejewski, R. (2017) 'Survey of judo injuries in physical education classes: a retrospective analysis', Journal of Physical Education and Sport, 17(3), pp. 2034-2042.

Lenetsky, S. and Harris, N. (2012) 'The mixed martial arts athlete: a physiological profile', Strength \& Conditioning, 34(1), pp. 32-47. https://doi.org/10.1519/ssc.0b013e3182389f00

Murzinova, K. E. A., Koblanova, A., \& Ansabayeva, D. A. A. (2018). Prosodical means applied in communicative relations. Opción, 34(85-2), 61-96.

Myers, T., Nevill, A. and AI Nakeeb, Y. (2013) 'A comparison of the effect of two different judging systems on the technique selection of Muay Thai competitors', Journal of Human Sport and Exercise, 8(3), pp. 761-777. https://doi.org/10.4100/jhse.2013.83.01

Nugroho, A. (2004) Dasar-dasar Pencak Silat. Yogyakarta: Universitas Negeri Yogyakarta.

Puspitasari, L., In'am, A., \& Syaifuddin, M. (2019). Analysis of Students' Creative Thinking in Solving Arithmetic Problems. International Electronic Journal of Mathematics Education, 14(1), 49-60. https://doi.org/10.12973/iejme/3962

Sajoto, M. (1988) Pembinaan Kondisi Fisik dalam Olahraga. Jakarta: Depdikbud.

Santos, C. A., Tainsky, S., Schmidt, K.A., and Shim, C. (2013) 'Framing the octagon: An analysis of news-media coverage of mixed martial arts', International Journal of Sport Communication, 6(1), pp. 66-86. https://doi.org/10.1123/ijsc.6.1.66

Siswantoyo, S. and Graha, A. S. (2016) 'Pengembangan coloring book dan puzzle teknik dasar pencak silat', Jurnal Olahraga Prestasi, 12(1), pp. 1-15.

Somantri, A. and Muhidin, S. A. (2006) Aplikasi Statistika dalam Penelitian. Bandung: Pustaka Setia. 


\section{(c) (1) (9)}

This work is licensed under a Attribution-NonCommercial-NoDerivatives 4.0 International (CC BY-NC-ND 4.0). 